\title{
Erratum to: Microstructural and Stress Corrosion Cracking Characteristics of Austenitic Stainless Steels Containing Silicon
}

\author{
PETER L. ANDRESEN, PETER H. CHOU, MARTIN M. MORRA, \\ J. LAWRENCE NELSON, and RAUL B. REBAK
}

DOI: $10.1007 / \mathrm{s} 11661-009-0090-0$

(C) The Minerals, Metals \& Materials Society and ASM International 2009

\section{Erratum to: METALLURGICAL AND MATERIALS TRANSACTIONS A DOI: 10.1007/s11661-009-9960-8}

IN the acknowledgments section of the original article, the locations of Tohoku University and the Electric Power Research Institute were incorrectly cited. In addition, the contract \# was inadvertently attributed to the wrong institution. The publisher regrets the error.
The corrected acknowledgments are as follows:

The technical expertise of Bill Catlin, Mike Pollick, Steve Buresh, Tony Barbuto, David Wark, James Evertsen, and James Grande is gratefully acknowledged. The authors are grateful to Yoichi Takeda and Tetsuo Shoji from Tohoku University, Sendai, Japan for sending some of the material used for testing. This work was funded by the Electric Power Research Institute (Contract \# EP - P26520/C12734), Palo Alto, CA.
PETER L. ANDRESEN and RAUL B. REBAK, Research Scientists, and MARTIN M. MORRA and J. LAWRENCE NELSON, Laboratory Managers, are with the GE Global Research Center, Schenectady, NY 12309. Contact e-mail: rebak@ge.com PETER H. CHOU, Program Manager, is with the Electric Power Research Institute, Palo Alto, CA 94304.

The online version of the original article can be found under doi: 10.1007/s11661-009-9960-8.

Article published online October 15, 2009 